\title{
PENGARUH KREDIBILITAS PERUSAHAAN DAN BINTANG IKLAN TERHADAP KEPUTUSAN KONSUMEN UNTUK MEMBELI SEPEDA MOTOR HONDA VARIO PADA CV. INDAKO TRADING CO RANTAUPRAPAT
}

\author{
Surya Bhakti ${ }^{1}$, dan Muda Pardamean Nasution² \\ ${ }^{1}$ Alumni STIE Labuhanbatu \\ ${ }^{2}$ Dosen STIE Labuhanbatu
}

\begin{abstract}
Abstrak
Tujuan dari penelitian ini adalah untuk mengetahui pengaruh kredibilitas perusahaan dan kredibilitas bintang iklan terhadap keputusan konsumen untuk membeli sepeda motor Honda Vario pada CV. Indako Trading Co Rantauprapat, baik secara parsial dan simultan. Penelitian ini menggunakan 86 responden sebagai sampel penelitian yang diambil dengan menggunakan teknik accidental sampling. Hasil penelitian berdasarkan uji secara serempak (uji F) menunjukkan bahwa secara simultan (serempak) kredibilitas perusahaan dan kredibilitas bintang iklan berpengaruh positif dan signifikan terhadap keputusan konsumen untuk membeli sepeda motor Honda Vario pada CV. Indako Trading Co Rantauprapat. Hasil pengujian hipotesis secara parsial (uji t) menunjukkan bahwa kredibilitas perusahaan dan kredibilitas bintang iklan secara parsial berpengaruh positif dan signifikan terhadap keputusan konsumen untuk membeli sepeda motor Honda Vario pada CV. Indako Trading Co Rantauprapat. Variabel yang peling dominan berpengaruh terhadap keputusan konsumen adalah kredibilitas perusahaan. Berdasarkan hasil uji determinasi diketahui bahwa keputusan konsumen membeli sepeda motor Honda Vario pada CV. Indako Trading Co Rantauprapat mempu dijelaskan oleh kredibilitas perusahaan dan kredibilitas bintang iklan sebesar 45,9\%, sementara sisanya sebesar $54,1 \%$ dipengaruhi faktor lain yang tidak dibahas dalam penelitian ini, misalnya harga, kualitas produk, desain, dan lain sebagainya.
\end{abstract}

Kata kunci : Kredibilitas perusahaan, Kredibilitas bintang iklan, Keputusan konsumen

\section{PENDAHULUAN}

Persaingan di dunia otomotif saat ini semakin ketat dan semua distributor produk otomotif berlomba-lomba untuk menciptakan sebuah inovasi baru yang bisa menarik perhatian masyarakat dan saat ini produk sepeda motor matic sudah mulai dilirik oleh masyarakat sebagai salah satu alat transportasi yang sederhana dan mudah untuk digunakan. Untuk menghadapi persaingan ini Honda meluncurkan sebuah terobosan baru yaitu Honda Vario. Honda Vario memang bukan pioneer dalam jenis ini. Pesaing kuatnya (Yamaha) lebih dahulu melakukan terobosan dalam industri sepeda motor matic.

Respon positif masyarakat juga tercermin dari penjualan Honda Vario eSP series sebesar 1.382.486 unit dan tingginya pertumbuhan penjualan Honda Scoopy eSP sebesar $35,4 \%$ dari 285.830 unit pada 2014 menjadi 386.953 unit pada 2015. Penjualan skutik Honda lainnya tercatat yaitu Honda Spacy 7.258 unit, dan Honda PCX 3.852 unit, dan big bike skutik Honda NM4 Vultus terjual sebanyak 13 unit.

Dalam melakukan kegiatan pemasaran perusahaan masa kini dituntut untuk tidak hanya lebih dari sekedar menciptakan dan mengembangkan suatu produk yang 
berkualitas, menentukan harga yang menarik, kemudian menyalurkannya kepada konsumen, tetapi perlu juga untuk berkomunikasi dengan para pelanggan mereka sekarang dan calon pelanggan mereka di masa yang akan datang. Perusahaan harus melakukan kegiatan komunikasi pemasaran yang dapat digunakan oleh perusahaan untuk memberikan informasi kepada para konsumen mengenai produk yang dihasilkan dan memposisikan produk perusahaan tersebut secara tepat dibenak konsumen. Salah satu kegiatan yang dapat dilakukan oleh perusahaan untuk mengkomunikasikan produk yang dihasilkannya adalah dengan melakukan kegiatan periklanan. Iklan sendiri selain menyediakan informasi mengenai produk juga berfungsi untuk mempersuasi potential buyer atas produk yang ditawarkan.

Honda dalam kampanye periklanannya menghadirkan Agnes Monica sebagai bintang iklan untuk produk Honda Vario, yang diharapkan mampu menarik konsumen agar melirik dan membeli sepeda motor matic. Agnes Monica yang dikenal sebagai artis populer di Indonesia.

Penelitian ini dilakukan untuk mengetahui sejauh mana pengaruh kredibilitas perusahaan dan bintang iklan terhadap keputusan konsumen untuk sepeda motor Honda Vario pada CV. Indako Trading Co Rantauprapat. Hal ini dikarenakan CV. Indako Trading Co Rantauprapat merupakan main dealer sepeda motor Honda untuk wilayah Labuhanbatu dengan penjualan yang cukup tinggi. Banyaknya tipe sepeda motor matic yang ada di pasar merupakan masalah yang dihadapi oleh masyarakat yaitu bagaimana memilih sepeda motor matic yang sesuai dengan harapan dan memenuhi keinginan. Konsumen membutuhkan banyak pertimbangan sebelum melakukan pembelian produk. Memilih sepeda motor yang handal merupakan suatu hal yang penting untuk menunjang aktivitas, tentunya konsumen harus kritis memperhatikan merek sepeda motor yang mana yang menguntungkan dan memuaskan bagi mereka.

\section{TINJAUAN PUSTAKA}

Dalam membangun kredibilitas perusahaan, ada 3 hal yang menjadi dimensi utamanya yaitu : honesty (kejujuran), competence (kompetensi), dan inspiration (inspirasi). Kejujuran menumbuhkan kepercayaan dari berbagai pihak terhadap perusahaan. Kompetensi yang memelihara kepercayaan yang sudah tumbuh tersebut. Perusahaan dituntut untuk memperlihatkan kompetensi tanpa cela di bidangnya agar kepercayaan yang sudah ditumbuhkan diawal tidak hilang oleh berbagai kekecewaan. Sedangkan dimensi inspirasi yang mempertahankan kepercayaan agar tidak beralih pada perusahaan lain.

Kredibilitas perusahaan memiliki pengaruh langsung terhadap keputusan membeli (Lafferty dan Goldsmith dalam Yusnita, 2010:29). Dalam menilai produk perusahaan dan menentukan apakah mereka ingin membelinya, konsumen menggunakan persepsi terhadap kejujuran dan keahlian perusahaan sebagai sumber informasinya. Penelitian yang dilakukan oleh Goldsmith et.al (dalam Yusnita, 2010:31) juga mendukung hubungan langsung antara kredibilitas perusahaan dan keputusan membeli. Keputusan pembelian produk sebagian dipengaruhi oleh kredibilitas perusahaan.

Penggunaan narasumber (source) sebagai figur penarik perhatian dalam iklan merupakan salah satu cara kreatif untuk menyampaikan pesan (Kotler dan Keller, 2006:160). Pesan yang disampaikan oleh nara sumber yang menarik akan lebih mudah dan menarik perhatian konsumen. Penggunaan selebriti di dalam mendukung iklan memiliki empat alasan utama, yaitu : pemasar rela membayar tinggi selebriti yang banyak disukai oleh masyarakat, selebriti digunakan untuk menarik perhatian khalayak dan 
meningkatkan kesadaran produk, pemasar mengharapkan persepsi konsumen terhadap produk tersebut akan berubah, penggunaan selebriti menimbulkan kesan bahwa konsumen selektif dalam memilih dan meningkatkan status dengan memiliki apa yang digunakan oleh selebriti.

Tugas utama para bintang iklan ini adalah untuk menciptakan asosiasi yang baik antara bintang iklan dengan produk yang diiklankan sehingga timbul sikap positif dalam diri konsumen, sehingga iklan dapat menciptakan citra yang baik pula di mata konsumen. Iklan merupakan elemen yang penting dan saling berpengaruh dalam menanamkan kesadaran merek kepada konsumen, seiring dengan ciri fisik dan kualitas produk yang mengikuti suatu merek tertentu.

Bintang iklan sebagai opinion leader yang menyampaikan pesan hingga sampai ke konsumen mengenai merek produk. Opinion Leader berperan dalam memberikan informasi pada orang lain, pelaku persuasi, dan pemberi informasi. Menurut Ohanian (dalam Royan, 2006:8) kredibilitas bintang iklan secara umum dapat digeneralisasikan meliputi tiga dimensi, yaitu daya tarik (attractiveness), dapat dipercaya (trusworthiness), keahlian (expertise). Konsumen akan lebih tertarik untuk melakukan pembelian terhadap suatu barang dan jasa yang telah didukung oleh selebriti dibandingkan dengan barang atau jasa yang tidak didukung selebriti.

Berdasarkan teori-teori yang dikemukan, maka model kerangka konseptual dari penelitian ini adalah sebagai berikut :

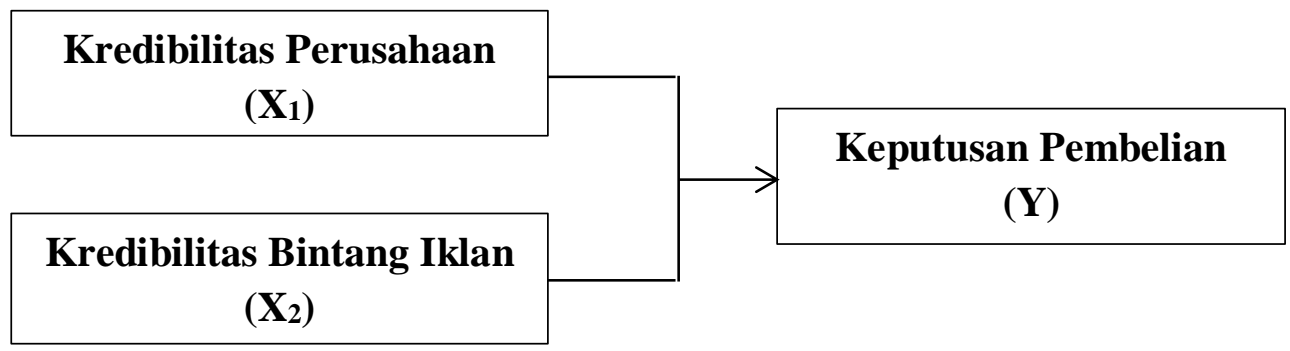

Gambar 1 Kerangka Konseptual

Berdasarkan perumusan masalah yang telah dikemukakan diatas, maka hipotesis penelitian ini adalah :

1. Kredibilitas perusahaan berpengaruh positif dan signifikan terhadap keputusan konsumen untuk membeli sepeda motor Honda Vario pada CV. Indako Trading Co Rantauprapat.

2. Kredibilitas bintang iklan berpengaruh positif dan signifikan terhadap keputusan konsumen untuk membeli sepeda motor Honda Vario pada CV. Indako Trading Co Rantauprapat.

3. Kredibilitas perusahaan dan Kredibilitas bintang iklan berpengaruh positif dan signifikan terhadap keputusan konsumen untuk membeli sepeda motor Honda Vario pada CV. Indako Trading Co Rantauprapat.

\section{METODE}

\section{Populasi dan Sampel}

Menurut Sugiyono (2008:72) populasi adalah wilayah generalisasi yang terdiri dari objek yang memepunyai kualitas dan karakteristik tertentu yang dapat ditetapkan oleh peneliti untuk dipelajari dan kemudian ditarik kesimpulannya. Populasi dalam 
penelitian ini adalah konsumen yang membeli sepeda motor Honda Vario di CV. Indako Trading Co Rantauprapat, sesuai data penjualan tahun 2015 sebanyak 597 orang.

Menurut Sugiyono (2008:78) sampel adalah bagian dari jumlah dan karakteristik yang dimiliki oleh populasi tersebut. Teknik sampling yang digunakan dalam penelitian ini adalah Teknik aksidental sampling. Aksidental sampling adalah teknik penentuan sampel berdasarkan kebetulan yaitu siapa saja yang kebetulan dapat digunakan sebagai sampel jika orang yang ditemui tersebut dianggap cocok sebagai sampel.

Teknik penarikan jumlah sampel yang digunakan dalam penelitian ini adalah menggunakan rumus Slovin dalam Situmorang dan Ginting (2008:151), yaitu :

$$
\begin{aligned}
& n=\frac{N}{\left(1+N e^{2}\right)} \\
& n=\frac{597}{\left(1+597(10 \%)^{2}\right)} \\
& n=85,65
\end{aligned}
$$

Dengan demikian jumlah sampel dibulatkan menjadi 86 responden.

\section{Teknik Pengumpulan Data}

Teknik pengumpulan data dalam penelitian ini adalah :

1. Daftar Pernyataan (Kuesioner), merupakan teknik pengumpulan data yang dilakukan dengan memberikan sejumlah daftar pertanyaan atau pernyataan yang tertulis kepada responden untuk dijawabnya.

2. Wawancara (Interview), merupakan suatu jenis pengumpulan data dimana peneliti mengajukan pertanyaan secara lisan untuk mendapatkan informasi apakah responden yang ditemui adalah penguna sepeda motor merek Honda

3. Studi Dokumentasi, yaitu mengumpilkan data melalui buku, jurnal, majalah, internet yang menjadi bahan referensi pendukung bagi peneliti.

\section{Metode Analisis Data}

\section{Metode Analisis Deskriptif}

Analisis deskriptif adalah kegiatan mengelompokkan, memisahkan, mengatur, mengurutkan, menganalisis serta menyimpulkan data sehingga hasilnya dapat ditafsirkan dan memberikan informasi deskriptif untuk menjawab pertanyaan dari defenisi masalah.

\section{Metode Analisis Statistik}

Metode ini digunakan penulis untuk mengetahui pengaruh hubungan dari variabel-variabel independen, yaitu kredibilitas perusahaan $\left(\mathrm{X}_{1}\right)$ dan kredibilitas bintag iklan $\left(\mathrm{X}_{2}\right)$ terhadap variabel dependen yaitu keputusan konsumen $(\mathrm{Y})$. Metode regresi linier berganda dalam penelitian ini menggunakan bantuan SPSS 20.0 for Windows. Adapun model persamaan yang digunakan (Sugiyono, 2008) yaitu :

$$
Y=a+b_{1} X_{1}+b_{2} X_{2}+e
$$

Keterangan :

$\mathrm{Y}=$ Keputusan konsumen

$\mathrm{X}_{1}=$ Kredibilitas perusahaan

$\mathrm{X}_{2}=$ Kredibilitas bintang iklan

$\mathrm{b}_{1}, \mathrm{~b}_{2}=$ koefisien regresi

$\mathrm{a} \quad=$ konstanta

$e \quad=$ standar error 


\section{HASIL DAN PEMBAHASAN}

\section{Hasil Analisis Regresi Linear Berganda}

Dalam melakukan analisis regresi linear berganda digunakan bantuan aplikasi SPSS versi 20. Hasil pengolahan data ditampilkan seperti pada Tabel berikut :

Tabel 1 Hasil Analisis Regresi Linear Berganda Coefficients $^{\mathrm{a}}$

\begin{tabular}{|ll|c|c|c|c|c|}
\hline \multirow{2}{*}{ Model } & \multicolumn{2}{|c|}{$\begin{array}{c}\text { Unstandardized } \\
\text { Coefficients }\end{array}$} & $\begin{array}{c}\text { Standardized } \\
\text { Coefficients }\end{array}$ & \multirow{2}{*}{ Sig. } \\
\cline { 2 - 5 } & $\mathrm{B}$ & $\begin{array}{c}\text { Std. } \\
\text { Error }\end{array}$ & Beta & & \\
\cline { 2 - 5 } & (Constant) & 3,507 & 1,768 & & 1,984 &, 051 \\
1 & Kredibilitas perusahaan &, 632 &, 113 &, 535 & 5,576 &, 000 \\
& Kredibilitas bntg iklan &, 179 &, 076 &, 226 & 2,361 &, 021 \\
\hline
\end{tabular}

a. Dependent Variable: Keputusan pembelian

Sumber : Hasil Penelitian (Diolah SPSS), 2016

Berdasarkan Tabel pada kolom Unstandardized Coefficients diperoleh nilai konstansta dan koefisien regresi sebagai berikut :

$\mathrm{a}=3,507$, artinya bahwa jika variabel kredibilitas perusahaan dan kredibilitas bintang iklan tidak ada, maka keputusan konsumen membeli sepeda motor Honda Vario sebesar 3,507.

$\mathrm{b}_{1}=0,632$, artinya bahwa jika variabel kredibilitas perusahaan $\left(\mathrm{X}_{1}\right)$ naik satu satuan dan variabel lainnya konstan, akan meningkatkan keputusan konsumen untuk membeli sepeda motor Honda Vario sebesar 0,632.

$\mathrm{b}_{2}=0,179$, artinya bahwa jika variabel kredibilitas bintang iklan $\left(\mathrm{X}_{2}\right)$ naik satu satuan dan variabel lainnya konstan, akan meningkatkan keputusan keputusan konsumen untuk membeli sepeda motor Honda Vario sebesar 0,179.

Dari hasil tersebut, maka persamaan linear sebagai berikut :

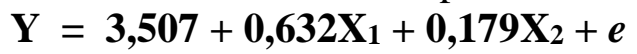

Dengan melihat bahwa seluruh koefisien regresi bernilai positif, artinya kredibilitas perusahaan dan kredibilitas bintang iklan memiliki hubungan positif terhadap keputusan konsumen untuk membeli sepeda motor Honda Vario pada CV. Indako Trading Co Rantauprapat.

\section{Pengujian Hipotesis}

Uji Hipotesis yang digunakan adalah uji signifikansi parsial (uji t) dan uji signifikansi simultan (uji F)

\section{Uji Signifikansi Parsial (Uji t)}

Uji parsial (Uji t) digunakan untuk menguji tingkat signifikasi variabel X terhadap $Y$ secara parsial. Pengujian dilakuakn dengan mebandingkan nilai $t_{\text {hitung }}$ dengan $t_{\text {tabel }}$. Nilai $t_{\text {hitung }}$ diperoleh dari pengolahan SPSS, sedangkan nilai $t_{\text {tabel }}$ menggunakan nilai distribusi $\mathrm{t}$ dengan taraf signifikansi 0,05 pada derajat kebebasan $(\mathrm{df}=\mathrm{n}-\mathrm{k})=86-3=83$, maka nilai $\mathrm{t}_{\text {tabel }}(5 \%: 83)$ sebesar $1,66342=1,663$. 
Tabel 2 Hasil Uji t

Coefficients $^{\mathrm{a}}$

\begin{tabular}{|l|r|r|r|r|r|}
\hline \multirow{2}{*}{ Model } & \multicolumn{2}{|c|}{$\begin{array}{c}\text { Unstandardized } \\
\text { Coefficients }\end{array}$} & $\begin{array}{l}\text { Standardized } \\
\text { Coefficients }\end{array}$ & \multirow{2}{*}{ Sig. } \\
\cline { 2 - 5 } & \multicolumn{1}{|c|}{ B } & Std. Error & \multicolumn{1}{c|}{ Beta } & \\
\hline $\begin{array}{l}\text { (Constant) } \\
\begin{array}{l}\text { Kredibilitas } \\
\text { perusahaan }\end{array}\end{array}$ & 3,507 & 1,768 & & 1,984 &, 051 \\
$\begin{array}{l}\text { Kredibilitas bntg } \\
\text { iklan }\end{array}$ &, 632 &, 113 &, 535 & 5,576 &, 000 \\
\hline
\end{tabular}

a. Dependent Variable: Keputusan pembelian

Sumber : Hasil Penelitian (Diolah SPSS), 2016

Berdasarkan hasil output SPSS pada Tabel diatas, maka nilai $t_{\text {hitung }}$ dari tiap variabel $\mathrm{X}$ dibandingkan dengan nilai $\mathrm{t}_{\text {tabel }}$ sebagai berikut :

1. Untuk variabel kredibilitas perusahaan $\left(X_{1}\right)$ diperoleh hasil nilai $t_{\text {hitung }}(5,576)>t_{\text {tabel }}$ $(1,663)$ dengan taraf signifikan $0,000<0,05$. Hasil tersebut menunjukkan bahwa kredibilitas perusahaan berpengaruh positif dan signifikan terhadap keputusan konsumen membeli sepeda motor Honda Vario pada CV. Indako Trading Co Rantauprapat. Dengan demikian hipotesis dapat diterima.

2. Untuk variabel kredibilitas bintang iklan $\left(X_{2}\right)$ diperoleh hasil nilai thitung $(2,361)>t_{\text {tabel }}$ $(1,663)$ dengan taraf signifikan $0,021<0,05$. Hasil tersebut menunjukkan bahwa kredibilitas bintang iklan berpengaruh positif dan signifikan signifikan terhadap keputusan konsumen membeli sepeda motor Honda Vario pada CV. Indako Trading Co Rantauprapat. Dengan demikian hipotesis dapat diterima.

\section{Uji Signifikansi Simultan (Uji F)}

Uji simultan (Uji F) digunakan untuk menguji pengaruh kredibilitas perusahaan $\left(\mathrm{X}_{1}\right)$ dan kredibilitas bintang iklan $\left(\mathrm{X}_{2}\right)$ secara bersama-sama terhadap keputusan konsumen membeli sepeda motor Honda Vario pada CV. Indako Trading Co Rantauprapat (Y). Uji F dilakukan dengan membandingkan $F_{\text {hitung }}$ dan $F_{\text {tabel. }}$. Nilai $F_{\text {hitung }}$ diperoleh dari pengolahan SPSS, sedangkan $F_{\text {tabel }}$ diperoleh dari nilai distribusi $F$ pada derajat kebebasan $\mathrm{df}_{1}(3-1=2)$ dan $\mathrm{df}_{2}(86-3=83)$ yaitu 3,11 .

Tabel 3 Hasil Uji F ANOVA $^{\mathrm{a}}$

\begin{tabular}{|c|c|c|c|c|c|c|}
\hline \multicolumn{2}{|c|}{ Model } & $\begin{array}{c}\text { Sum of } \\
\text { Squares }\end{array}$ & Df & $\begin{array}{l}\text { Mean } \\
\text { Square }\end{array}$ & $\mathrm{F}$ & Sig. \\
\hline \multirow{3}{*}{1} & Regression & 159,108 & 2 & \multirow{3}{*}{$\begin{array}{r}79,554 \\
2,149\end{array}$} & \multirow[t]{3}{*}{37,014} & \multirow[t]{3}{*}{, $000^{\mathrm{b}}$} \\
\hline & Residual & 178,392 & 83 & & & \\
\hline & Total & 337,500 & 85 & & & \\
\hline
\end{tabular}

a. Dependent Variable: Keputusan pembelian

b. Predictors: (Constant), Kredibilitas bntg iklan, Kredibilitas perusahaan

Sumber : Hasil Penelitian (Diolah SPSS), 2016

Berdasarkan Tabel diatas diketahui bahwa $F_{\text {hitung }}(37,014)>\mathrm{F}_{\text {tabel }}(3,11)$ dengan taraf signifikan $0,000<0,05$. Hal ini berarti bahwa kredibilitas perusahaan $\left(\mathrm{X}_{1}\right)$ dan kredibilitas bintang iklan $\left(\mathrm{X}_{2}\right)$ secara bersama-sama berpengaruh positif dan signifikan terhadap keputusan konsumen membeli sepeda motor Honda Vario pada CV. Indako Trading Co Rantauprapat (Y). Dengan demikian hipotesis dapat diterima. 


\section{PEMBAHASAN}

Dari hasil pengujian hipotesis secara parsial menunjukkan kredibilitas perusahaan berpengaruh positif dan signifikan terhadap keputusan konsumen membeli sepeda motor Honda Vario pada CV. Indako Trading Co Rantauprapat, yang ditunjukkan dari nilai $t_{\text {hitung }}(5,576)>t_{\text {tabel }}(1,663)$ dengan taraf signifikan $0,000<0,05$. Konsumen menilai kredibilitas perusahaan produsen dan distributor cukup baik. Dorongan atau keinginan konsumen untuk membeli sepeda motor Honda Vario ada hubungannya dengan seberapa baik keyakinan orang tersebut terhadap pengalaman, citra, reputasi, kebenaran dan keahlian yang dimiliki perusahaan.

Variabel kredibilitas bintang iklan secara parsial juga berpengaruh positif dan signifikan terhadap keputusan konsumen membeli sepeda motor Honda Vario pada CV. Indako Trading Co Rantauprapat, yang ditunjukkan dari nilai thitung $(2,361)>t_{\text {tabel }}(1,663)$ dengan taraf signifikan 0,021 $<0,05$. Dari hasil deskriptif menunjukkan bahwa konsumen menilai keahlian yang dimiliki Agnes Monica dan Daniel Mananta dalam mengiklankan Honda Vario cukup baik. Keluwesan Agnes Monica ketika mengendarai sepeda motor Honda Vario membuat konsumen yakin terhadap keunggulan produk yang dibelinya. Keanggunan yang diperlihatkan Agnes Monica disaat mengendarai sangat sesuai dengan performa dari sepeda motor Honda Vario memberikan keyakinan kepada konsumen sebagai sebagai sepeda motor khusus wanita. Dengan tidak meninggalkan sisi kewanitaan disaat berkendaraan. Kelincahan Agnes Monica ketika mengendarai di jalan yang ramai memberikan kesan kepada konsumen bahwa sepeda motor Honda Vario simpel dan mudah untuk dikendarai khususnya oleh kaum wanita. Walaupun Agnes Monica merupakan artis yang cukup terkenal, cantik, muda dan berbakat namun jika tidak didukung oleh keahliannya dalam mengendarai sepeda motor Honda Vario, iklan tersebut tidak begitu menarik untuk dilihat.

Adapun variabel yang dominan mempengaruhi keputusan konsumen dalam membeli sepeda motor Honda Vario adalah variabel kredibilitas perusahaan. Walaupun iklan sepeda motor Honda Variio tersebut cukup menarik yang didukung oleh bintang iklan selebriti terkenal, tetapi tidak mampu memberikan dampak yang kuat bagi konsumen untuk melakukan pembelian. Sehingga konsumen membutuhkan dasar informasi lebih jauh sebagai dasar pertimbangannya dari pada sekedar membuat keputusan berdasarkan iklan tersebut.

Hasil penelitian ini sejalan dengan penelitian Yusnita (2010) yang berjudul Analisis Pengaruh Kredibilitas Bintang Iklan dan Kredibilitas Perusahaan Terhadap Keputusan Pembelian Sepeda Motor Honda Beat di Kota Medan, yang menyatakan bahwa kredibilitas perusahaan lebih dominan berpengaruh terhadap keputusan pembelian sepeda motor Honda Beat di Kota Medan.

Dari hasil pengujian hipotesis secara simultan menunjukkan kredibilitas perusahaan dan kredibilitas bintang iklan berpengaruh positif dan signifikan terhadap keputusan konsumen membeli sepeda motor Honda Vario pada CV. Indako Trading Co Rantauprapat, yang ditunjukkan dari nilai $F_{\text {hitung }}(37,014)>F_{\text {tabel }}(3,11)$ dengan taraf signifikan $0,000<0,05$.

Berdasarkan hasil uji determinasi, diperoleh hasil bahwa keputusan konsumen membeli sepeda motor Honda Vario pada CV. Indako Trading Co Rantauprapat mempu dijelaskan oleh kredibilitas perusahaan dan kredibilitas bintang iklan sebesar 45,9\%, sementara sisanya sebesar $54,1 \%$ dipengaruhi faktor lain yang tidak dibahas dalam penelitian ini, misalnya harga, kualitas produk, desain, dan lain sebagainya. 


\section{KESIMPULAN DAN SARAN \\ Kesimpulan}

Berdasarkan hasil penelitian, maka dapat diambil kesimpulan sebagai berikut :

1. Kredibilitas perusahaan berpengaruh positif dan signifikan secara parsial terhadap keputusan konsumen membeli sepeda motor Honda Vario pada CV. Indako Trading Co Rantauprapat, yang ditunjukkan dari nilai $t_{\text {hitung }}(5,576)>t_{\text {tabel }}(1,663)$ dengan taraf signifikan $0,000<0,05$.

2. Kredibilitas bintang iklan berpengaruh positif dan signifikan secara parsial terhadap keputusan konsumen membeli sepeda motor Honda Vario pada CV. Indako Trading Co Rantauprapat, yang ditunjukkan dari nilai $t_{\text {hitung }}(2,361)>t_{\text {tabel }}(1,663)$ dengan taraf signifikan $0,021<0,05$.

3. Kredibilitas perusahaan dan kredibilitas bintang iklan secara bersama-sama berpengaruh positif dan signifikan terhadap keputusan konsumen membeli sepeda motor Honda Vario pada CV. Indako Trading Co Rantauprapat, yang ditunjukkan dari nilai $F_{\text {hitung }}(37,014)>F_{\text {tabel }}(3,11)$ dengan taraf signifikan $0,000<0,05$.

4. Keputusan konsumen membeli sepeda motor Honda Vario pada CV. Indako Trading Co Rantauprapat mempu dijelaskan oleh kredibilitas perusahaan dan kredibilitas bintang iklan sebesar 45,9\%, sementara sisanya sebesar 54,1\% dipengaruhi faktor lain yang tidak dibahas dalam penelitian ini, misalnya harga, kualitas produk, desain, dan lain sebagainya.

5. Variabel yang dominan mempengaruhi keputusan konsumen dalam membeli sepeda motor Honda Vario adalah variabel kredibilitas perusahaan.

\section{Saran}

Berdasarkan kesimpulan diatas, maka peneliti memberikan saran sebagai berikut

1. Perusahaan harus terus mempertahankan dan meningkatkan kredibilitas perusahaannya, dengan cara menjaga reputasi dan citra yang dimilikinya serta terus mengkomunikasikan hal tersebut kepada target konsumennya. Beberapa cara yang dapat ditempuh oleh perusahaan, baik itu produsen mapuan dealer adalah mendapatkan pengakuan akan kualitas produk dari lembaga independen yang kredibel, menciptakan produk yang bermutu tinggi, terlibat dalam kegiatan sosial, serta meningkatkan efektivitas dari salesperson dan distributor perusahaan sebagai ujung tombak sarana berkomunikasi langsung kepada konsumen.

2. Perusahaan harus terus menggunakan bintang iklan yang memiliki kredibilitas tinggi sebagai bintang iklan. Bintang iklan ini dapat menjadi juru bicara bagi perusahaan tidak hanya dalam iklan, tetapi juga dalam program komunikasi terpadu lainnya yang dijalankan oleh perusahaan. Karena diposisikan sebagai sepeda motornya kawula muda, maka perusahaan harus konsisten menggunakan bintang iklan yang muda, enerjik dan berbakat untuk membintangi iklannya.

3. Bagi peneliti selanjutnya, agar menggali fakor-faktor lain misalnya menggunakan variabel lain atau menambah variabel bebas seperti pesan harga, kualitas peroduk, daya tarik iklan, frekuensi iklan, media iklan, yang berpengaruh terhadap keputusan konsumen untuk melakukan pembelian produk sepeda motor Honda Vario. 


\section{DAFTAR PUSTAKA}

Aritonang, Hani. 2012. "Analisis Pengaruh Jingle Iklan, Bintang Iklan, dan Pesan Iklan Terhadap Recall Audience (Studi Kasus Pada Iklan Honda dengan Jingle "One Heart" Terhadap Mahasiswa FE USU)". Jurnal FEB. Medan : Universitas Sumatera Utara.

Belch, E George, \& Michael A Belch. 2009. Advertising And Promotion: An Integrated Marketing Communications Perspective. Edisi 12 Terjemahan. Jakarta : Erlangga.

Ghozali, Imam. 2007. Aplikasi Analisis Multivariate dengan Program SPSS. Semarang : Badan Penerbit Universitas Diponegoro.

Hardiman, Ima. 2006. 400 Istilah PR Media dan Periklanan. Jakarta : Gagas Ulung.

Indriyani, Ni Wayan, I Wayan Suwendra, Ni Nyoman Yulianthini. 2014. "Pengaruh Kredibilitas, Daya Tarik Ikan, dan Keahlian Bintang Iklan Terhadap Keputusan Pembelian Sepeda Motor Yamaha Mio GT”. e-Journal Bisma. Universitas Pendidikan Ganesha Jurusan Manajemen (Volume 3 Tahun 2014).

Kotler, Philip dan Kevin Lane Keller. 2006. Manajemen Pemasaran. Jakarta : PT.Indeks. Kuncoro, Mudrajad. 2009. Metode Riset untuk Bisnis \& Ekonomi (Edisi 3). Jakarta : Erlangga.

Noviandra, Mahestu, 2006. "Analisis Pengaruh Model Iklan Terhadap Perilaku Pembelian Remaja, Kasus Pada Bintang Akademi Fantasi Indosiar”. Jurnal. Vol. 3 No.2.

Royan, M, Frans. 2006. Marketing Selebrities : Selebriti dalam Iklan dan Strategi Selebriti Memasarkan Diri Sendiri. Jakarta : PT. Elex Media Komputindo.

Shimp, Terence A. 2007. Advertising Promotion and Supplement Aspect of Integrated Marketing Communicatio. Fifth Edition; Alih Bahasa : Periklanan Promosi dan Aspek Tambahan Komunikasi Pemasaran Terpadu. Edisi Kelima. Terjemahan : Reyvani Syahrial. Jakarta : Erlangga.

Situmorang, Syafrizal Helmi, dan Paham Ginting. 2008. Analisis Data Untuk Manajemen dan Bisnis. Medan : USU Press.

Sugiyono. 2008. Metode Penelitian Bisnis. Cetakan Kesepuluh. Bandung : Alfabeta.

Yusnita. 2010. "Analisis Pengaruh Kredibilitas Bintang Iklan dan Kredibilitas

Perusahaan Terhadap Keputusan Pembelian Sepeda Motor Honda Beat di Kota Medan”. Jurnal FEB. Medan : USU. 